\title{
Watching for and Preventing Forest Fires
}

\author{
How the Forest Service is Protecting Our Standing Timber
}

By Day Allen Willey T HE greatest problem connected with natural resources is the care and protec tion of the woodlands in charge of the Forest Service. The many ways in which trees can be destroyed by fires, by heavy gales, and by drouth which dries up the earth below the roots, gives the ranger a task of great responsibility, particularly when it is considered that these men have over $160,000,000$ acres of timberland in their charge.

To appreciate the problem one must have a clear conception of the type of country included in the National Forests, and also some idea of its extent. Except for small areas in Florida, Minnesota, Michigan, Kansas, and the Dakotas, the National Forests include the great mountain watersheds of the West. They lie along the crest of the main divides of the Rockies, the Cascades, and the coast ranges. The country is therefore rough and mountainous, cut by gorges and canyons, and broken by almost impassable ranges and by unscalable peaks. Ther are two general forest types-open park area with timber confined to the north slopes, and densely forested regions where timber grows on both exposures. In the main, the park country of the principal divides and the very heavily timbered regions are in the west.

The work of fire prevention and control, although theoretically the same for both types, differs essentially in practical application. Each national forest, the unit of administration, contains from $1,000,000$ to $2,000,000$ acres. This is equivalent to an area from 30 to 50 miles wide and from 40 to 60 miles long. To protect such an area from fire, especially in view of the difficulties of transportation and communication, is exceedingly difficult.

Fire insurance appraisers, who have investigated various causes of ignition in cities and towns, concur in the conclusion that fully 90 per cent of the fires were due to causes which could have been

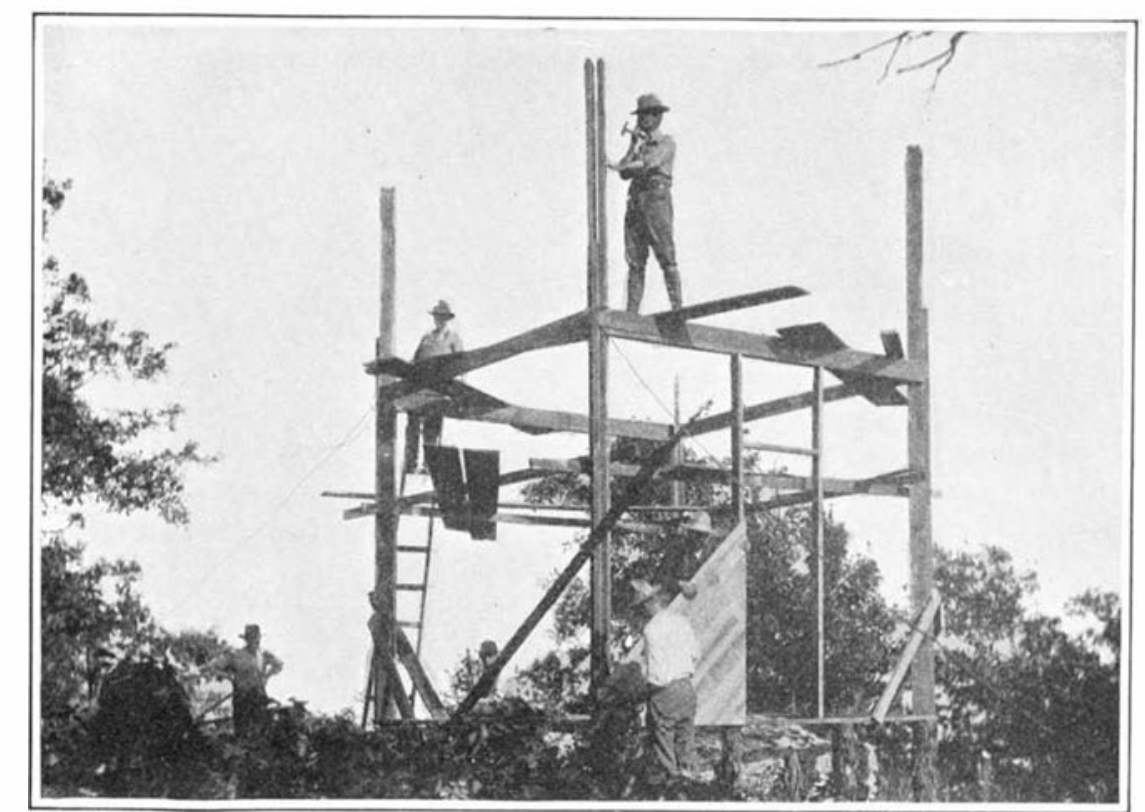

Building an observation tower to watch for fires.

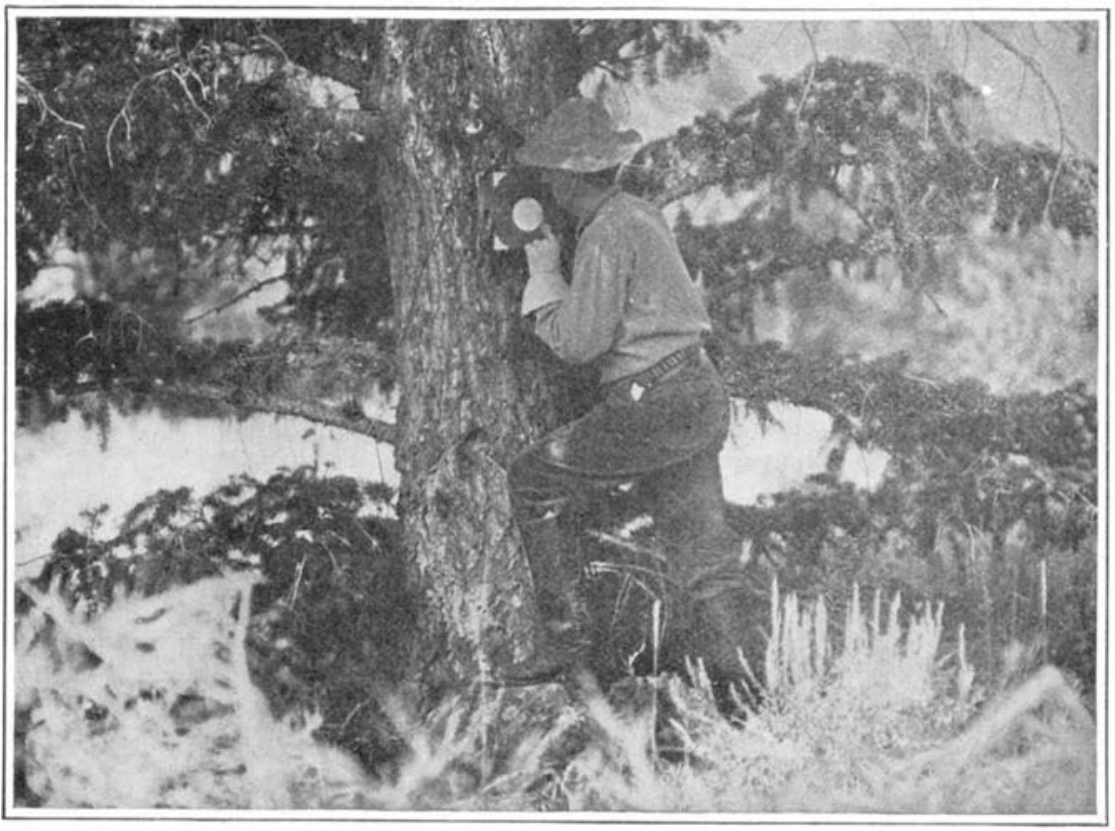

Rangers' telephone for giving fire alarms and reporting to their chief. avoided. Much of the loss by the flames in the woodland can be prevented. This statement is based on the opinion of the heads of the Forest Service division throughout the West, who have carefully studied the situation. As a result of their efforts, the service has already begun to execute plans which have proved to be practical and successful, either in preventing fire or in extinguishing it so soon after its origin that it did no damage. The burning of the timber means not only a loss in stumpage, but a community loss in wages of approximately $\$ 10$ for every thousand board feet destroyed. When it is realized that it is not uncommon for the timber to run from 50,000 to 100,000 board feet per acre in the dense forests of the Pacific Northwest, it is clear that it does not take very many burned acres to run the figures up to six or seven places. For example, from one year's fires in Montana and northern Idaho the loss was $6,000,000,000$ feet board measure, with an estimated value of $\$ 20,000,000$. Aside from the value of the timber the danger to lives and to town property from these large fires is a very great menace.

Always the first question when the fires are mentioned is: "How do all these fires get started?" The usual causes in the order of their frequency are: Railroad engines, lightning, careless campers, fishermen, and hunters; settlers burning brush to clear land for cultivation; logging engines and sawmills; malicious incendiaries. Out of 3,138 fires rèported, 1,186 were caused by locomotives, and their setting was due to three principal reasons-the use of coal as fuel, the lack of proper clearing of the right of way, and the non-use of spark arresters.

The railroad's right of way is usually from 100 to 200 feet wide. In many places within the National Forests the brush and debris have never been properly cleared up on the right of way after the larger timber has been removed, and (Continued on page 56.)

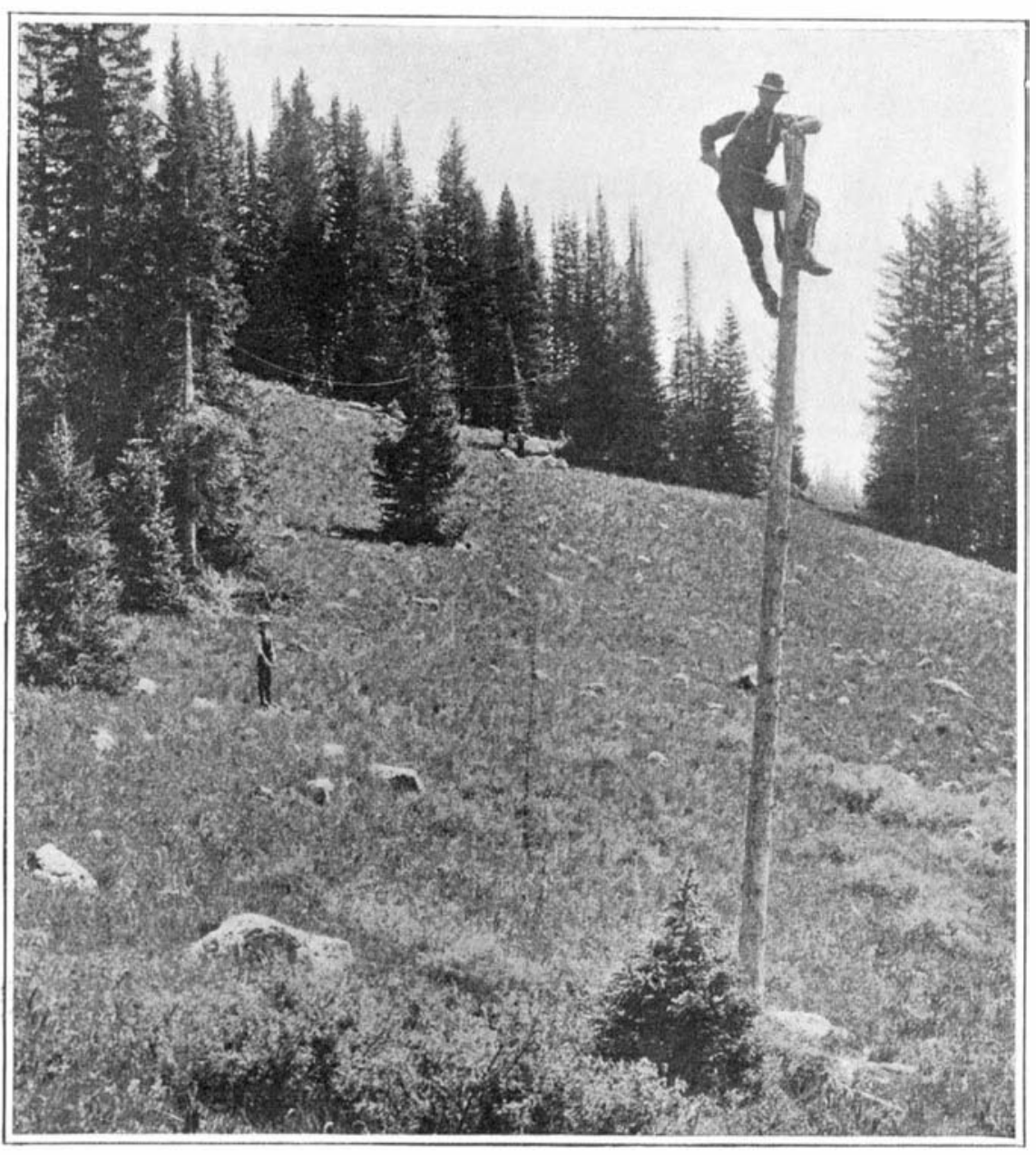

Running telegraph lines through reservations for rangers' use.

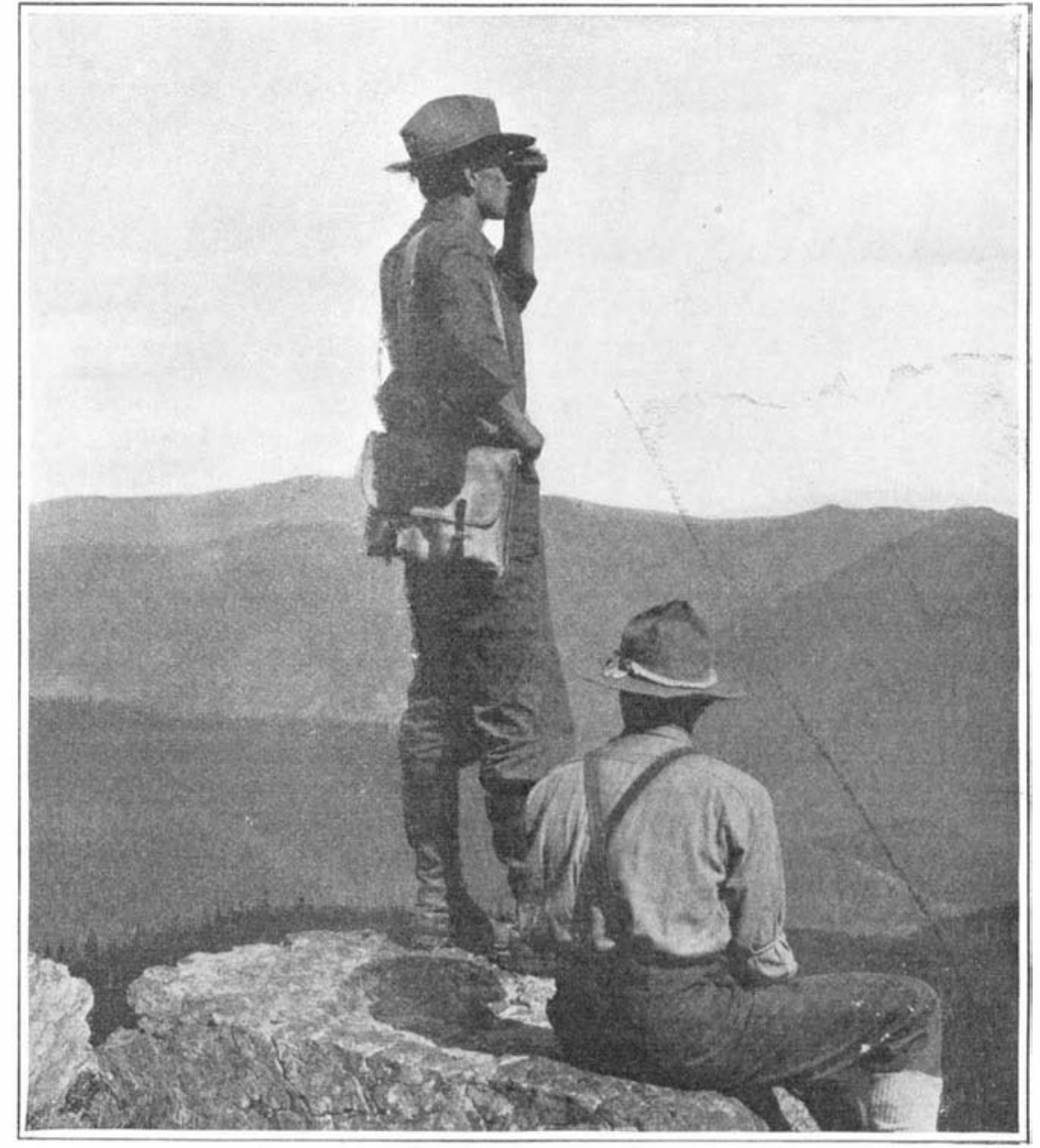

Ranger sweeping the Rocky Mountains for forest fires.

FIRE PROTECTION IN THE RSCKY MOUNTAIN FORESTS. 

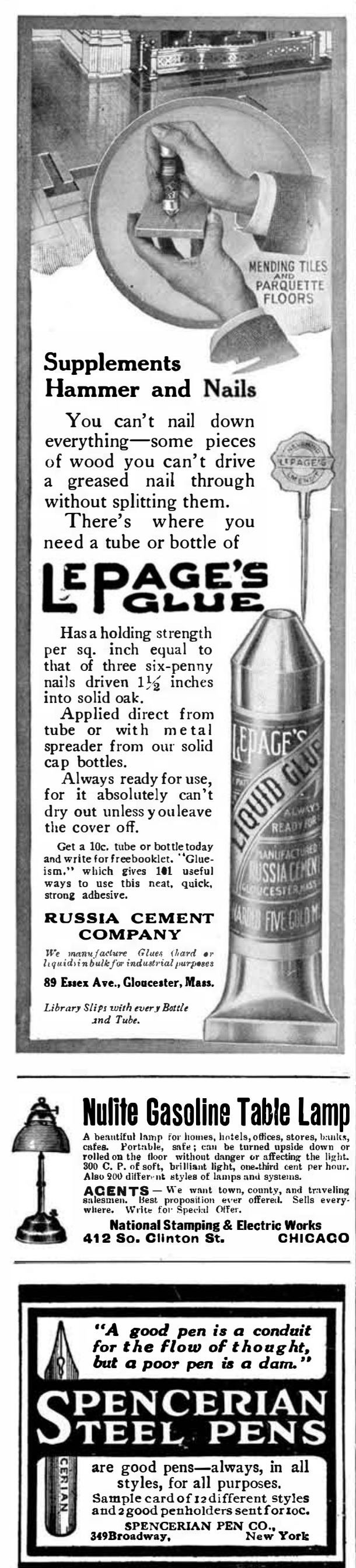

\section{Maxim Silencer}

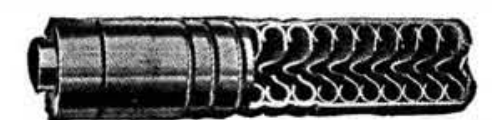

Specify Silencer equipment on your new rifle

Checks the muzzle blast, preventing report noise and recoil. Wonderful aid to marksmanship. 'Makes rifle practice possible anywhere. Attaches to any rifle. Write make, model and calibre of your rifle (giving dealer's name). We will tell you what Silencer you need, price, etc.

\section{Maxim Silencer} Fivirtford

\section{(Tarrespantùnte}

ance from any of the devices provided. (tatements made in the correspondence ditions change so that he has a speed connot re the air. This may save him ; cannot be considered, but the names of

The Technique of Clam Digging

The Technique of Clam Digging

It is amusing, when we think we know a thing thoroughly, to find we
know all about a given subject.

know all about a given subject.
Clam digging and its technique is simple matter, yet Mr. Johnson of Seat tle has never "dug" the festive "fan"
clam, and, though living in a clam country, and a city whose people certainly cannot be accused of clam natures, woul probably dispute the fact that there are swim. The clam commonly known as the "fan" clam must be taken with a rake or can on the end of a pole

ake handle out of a boat.

I have had hours of sport getting these them.

They lie on top of sandy stretches of the beach, close to or under sea weeds, and are very quick in their zigzag motions when disturbed, darting up, around, and through the water, and if the "clam ing of the habits of the "fan" clam, it is doubtful if he ever sees them, to say nothing of capturing any.

The shells are covered with a fuzzy substance which falls off after the clam is boilea, leaving thin, delicately colored,
ribbed shells, the ribs radiating like the ribbed shells, the ribs radiating like
leaves of a fan-hence their name.

The most common clam and the most edible is obtained by digging, as described y Mr. Johnson.

There is yet another clam that require a totally different technique. It is comtionary spelling is "geoduck," which "This carthduck."

This clam has to be dug for in earnest, would dig a deep hole for a telephone pole. Its neck is stretched as much
six feet, and its shells are as large as a six feet, and its shells are as large as that the shell on either side cannot that the shell on eith
opposite the hinge.

one more modern and larger locomotives
have a return draft, by which the larger banks along the edges of the Sound, and again at the very lowest tides it can be found deep down below the surface.
I have found five distinct "species" I have found five distinct "species" of
clams in quantities in Puget Sound, and clams in quantities in Puget Sound, and the clam family. Tacoma, Wasl.

Are There Any Holes in the Air? To the Editor of Scientiric turpicun: The numerous fatal accidents which have occurred in aeroplane work, and
which have involved the most skillful navigators of the air lead one to look fo some cause which is not allowed for or fully appreciated. We hear of "holes in the air" and such expressions, which are In thinking over this matter, it appears to
Int the writer that the fatal conditions are substantially two, and they are conditions which may overtake the most skillful and leave him entirely unprepared an lowing gust" and the other is the "slackening head wind." Let an aviator be flyening head wind." Let an aviator be flyspeed of progress with respect to the air
around him is say thirty miles an hour; around him is say thirty miles an hour;
now let the air back of him, as a "folnow let the air back of him, as a "fol-
lowing gust," suddenly increase to a speed equaling his own, and let this increase take place in a period of time which is too short for his machine to accelerate, that in spite of what little acceleration he gains, the "following gust" overtakes to the machine; that is, the machine and to the machine; that is, the machine and
the air in which he is immersed are mov the air in which he is immersed are mov-
ing forward at the same rate. At this moment all control apparatus fail; verti-
cal rudders, horizontal rudders, ailerons, everything, even the main planes, fail to have an effect, and the aeroplane is just
like a kite in the air with the string cut have an effect, and the aeroplane is just
like a kite in the air with the string cut,
liable to plunge in any direction to earth,
ceases, for lack of market, even the logs (Concluded from page us.) The second great cause of fires, and the
PATENTS

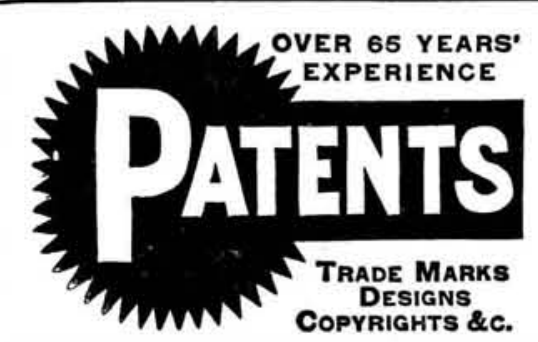

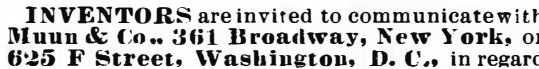

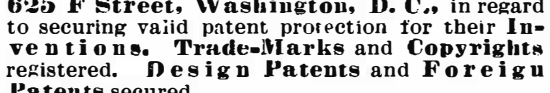

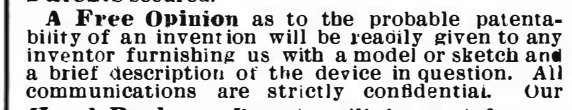
Ours is the Oldest agency for securing patents;
it was established over sixty-fire years ago. All patentssecured througn us are described with-
out cost to patentee in the Scientific American. MUNN \& C0., 36I Broadway, New York secret of the trouble, exist for a time, he is helpless, and may become the victim of a accident

It is manifest that a gustiness of the dangerous, but sudden accelerations and direction of his motion put him in immient danger by depriving him of all effece means of control.

I do not know how far these actions are discussed as the true causes of seen them difficulty in navigation of the air by aer

Watching for and Preventing Forest Fires

dry punk logs and débris form the most by a spark from the engine. Furthermore, the heavy grades in the mountains
require a full and forced exhaust on the ngines in order that sufficient steam may now in use interfere with the draft and, s a result, the wire screen must be engine may get up the difficult grades. have a return draft, by which the larger
cinders are forced back to the fire box before being emitted through the stack. Despite improvements, both in engines
and spark arresters, the railroads still and spark arresters, the railroads still
hold first place as a cause of forest fires. only one which can be classed as non-pre-
ventable, is lightning. During the dry ventable, is lightning. During the dry
season in 1910 there were many electrical season in 1910 there were many electrical
storms in the timber region and innumerable small fires were found immediately aftertward. If the storm is accompanied by rain there is, of course, little or no danger, but it is more usual for these
mountain electrical storms to be unaccompanied by rain. In 1909 there were cause.

Over 400,000 people go to the National or the people are out for a week or two at a time to hunt, fish, or just to ately many of the campers either are careless or are ignorant of the proper
handling of camp fires. The carelessness takes the form of leaving the fires unextinguished, or of throwing. about ciga or cigarette stumps or knocking out pipes. fuse that burns continuously to the end. The ignorance is shown in the failure to ing them in fairly open places and away rom punk logs and débiis. Frequently a large fire is built when a little one would
serve the purpose better and be safer. serve the purpose better and be safer.
Everyone who has been in the hills has un across the skeletons of old tepees that fireplace gives the impression of having fireplace gives the impression of having
been used for generations. It is simply a depression in the ground about 2 feet square, surrounded by a cleared space cout 10 feet in dianeter. Their fire proThe clearing of tim vation by settlers contributes materially cases, for lack of market, even the logs $\begin{aligned} & \text { is a cord.ductor of electricits, and the address of the } \\ & \text { makers of the same. }\end{aligned}$

\section{Classified Advertisements

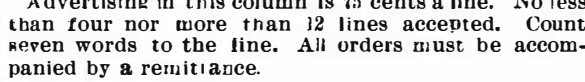 AUTOMOBILES.

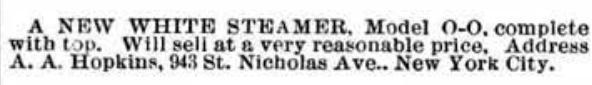 \\ BUSINESS OPPORTUNITIES.

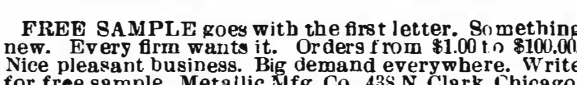

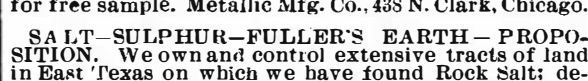

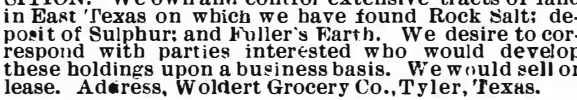

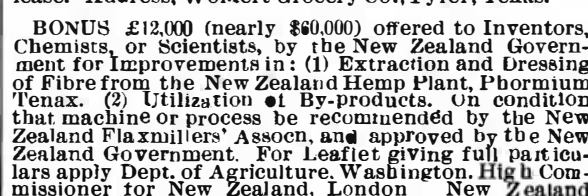

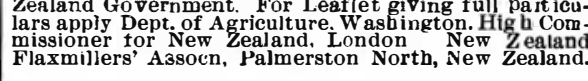

PATENTS FOR SALE.

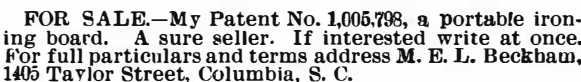

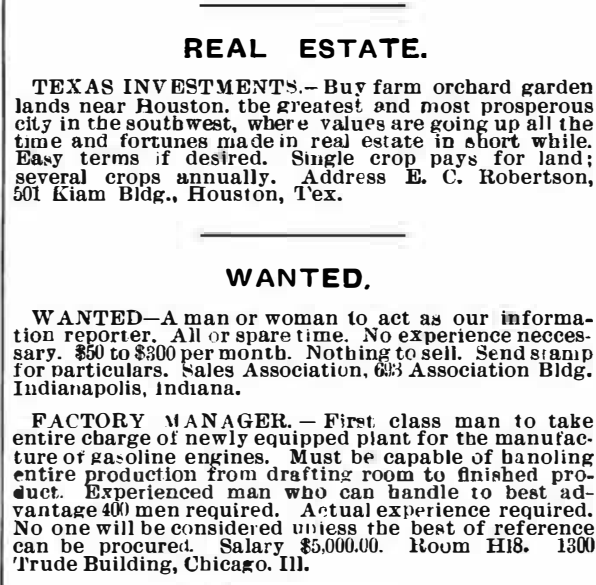

MISCELLANEOUS. ply to CARNEGIE COLILEGH, ROGERSS, OHIO.
"HEA VEN AND HELL"-Swedenborg's great wor

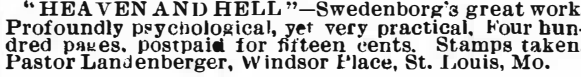

INQUIRY COLUMN READ THHS COLEMN CAREFULLYY- You will fnd
iuquiries for certain ciasses of articles numbered in
consecutive order. If yuu manufacture these goods orite us at ouce and we will send sou the name and
acidress of the parts desiring tbe infirmation. There

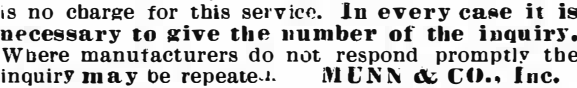
Inquiry No. 925.j.- Wanted, to buy a patent rol-
ler, a ball-bering axie - wich culd be purchased on a
royalty basis it must be cheap and fully proved. loyalty basis; it must be cheap and fully proved.
Inquiry No. g'2.5ti. Wanted addressee of parties
baving Pitchblende deposits, if able to stip ore. lnquiry No. 9.25\%. Wanted addresses of firms
selling second-hand water turbines. lnquiry No. $12 \bar{g} s$ s. - Wanted addresses of parties
having gem materials to offer in alis part of the world. Inquiry No. 2955:9. - Wanted to buy a machine for
remoring the coating of a tlbert.

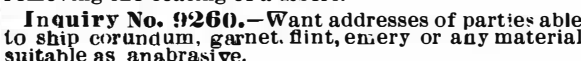
Ynquiry No. 9261. - Wanted, a manufacturer to
make card games

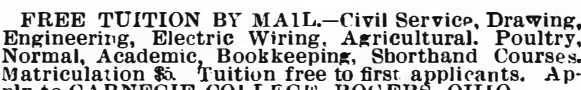




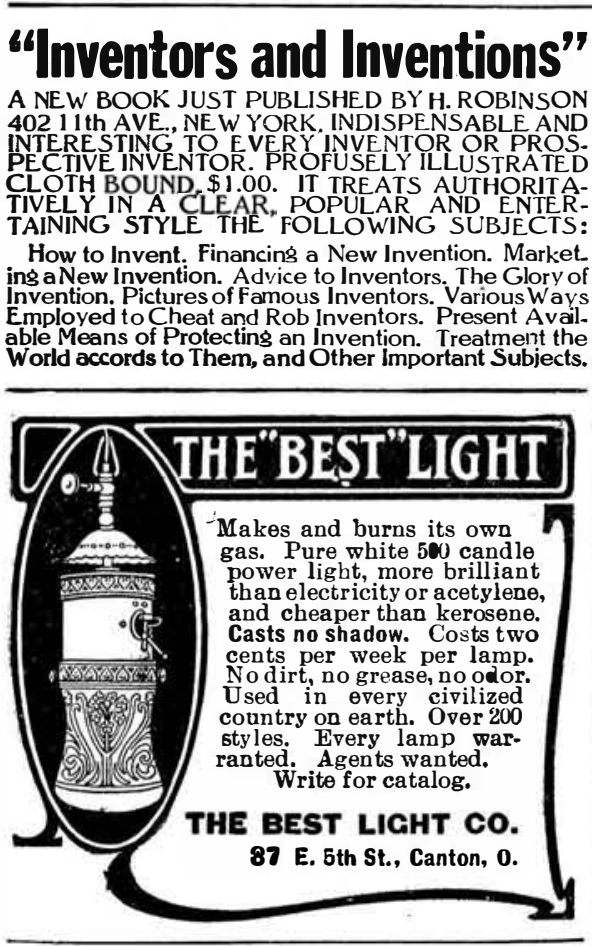

$\$ 1,725,000,000$

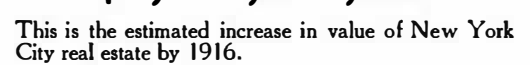

We purchase for permanent ownership the highest class
New York City income properties. There is a big
differencebetween ground floor ownershipand merely
lending money at fixed interest This difference has lending money at fred interest. This difference has
made many millionaires. To the individual investor
the inside opportunity is rare and in this case limited. Our booklet, "Wonders of the Magic City" tells a
fascinating story to the man or woman with $\$ 10,000$
or $\$ 10.00$ who invests for real profit. Complimentary upon request. Send for it toda.
new York Urban Real Estate Co. New York Urban Real Estate Co.
160 Broadway, N. Y

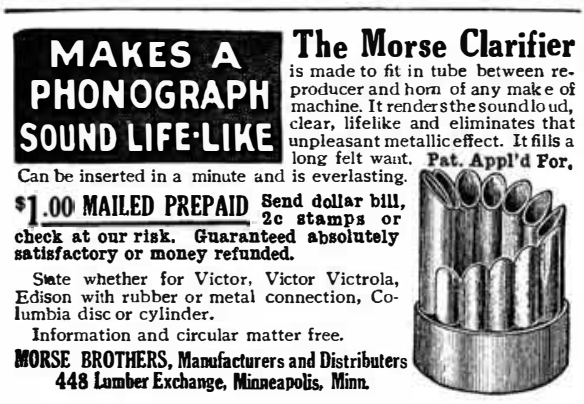

mance TABLOID' 'sano FIRST-AID

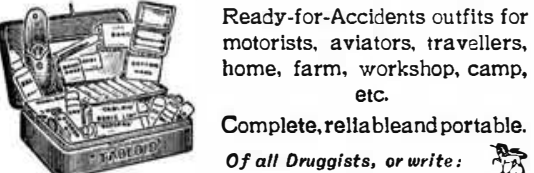
BURROUGHS WELLCOME \& Co., 35, West 33rd St., N.Y.

INVENTORS we build models, do light manufacturing dies and tools.

G. SCHWARZ \& CO., 123 Liberty St., N.Y

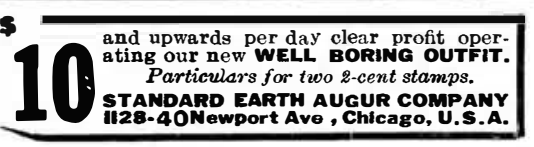

WANTED Malan Peture

write them; we teach you in ten easy lessons. Ours is the orignal and only thorough course; graduates selling their plays.
Write for details. Ass'd M. P. Schools, 603 Sheridan Rd, Chicago

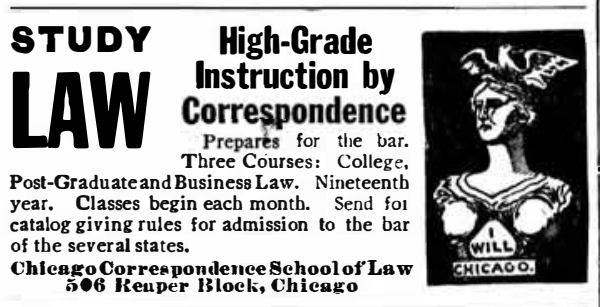

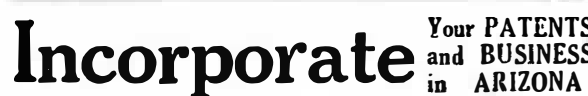

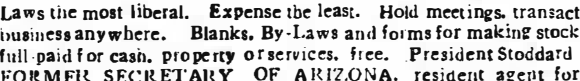

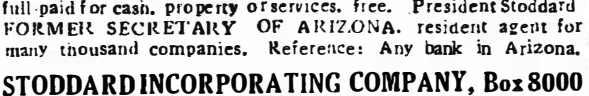
STODDARDINCORPORATING COMPANY, Bos 8000
PHOENIX, ARIZONA

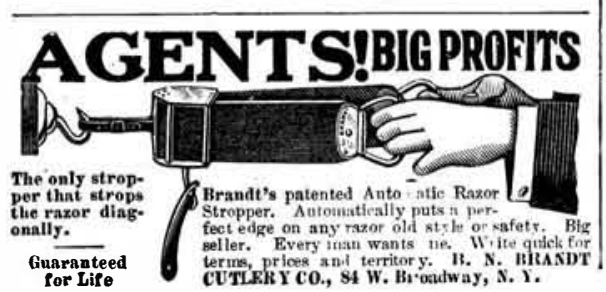

themselves are thus disposed of, in order to clean up the land. The increasing use
of donkey engines in logging has brought about a corresponding increase in fires, and logging locomotives passing through of the largest forest fires.

In the National Forests, of course, fire ing of can not be used; but the reportance, and the keeping in readiness of necessary tools and equipment are of much aid in preventing the spread of Modern devices are now being employed Of these the telephone is one of the most valuable. Already several thousand miles of line has been laid, with trees as poles. un, the ranger can reach a tree telephone danger. What this safeguard means, is fore the installation of the telephone, it was necessary for the ranger to ride to
the nearest settlement, where he gathered such help and supplies as he could with the least loss of time, and returned to the fire, after sending a messenger on to the mean time, hours had been lost, and they meant thousands of dollars waste to the nation. In one fire, because a privately owned telephone line in the national forest was out of repair, seven million feet of timber burned in one aftertelephone line before another season opened.
In the forest reserves of Montana and other parts of the Rocky Mountains the most important duty of the ranger is to watch for fires. It is a very dry coun-
try, and the woods are like so much tinder, which a spark may ignite. The
ranger, from his post of outlook on the top of a mountain that may be two miles
high, locates the fires with the help of a field-glass, and "plots" them on a sketch chart of the surrounding region. Then, descending to his cabin or to some other
station of communication, he telephones station of communication, he telephones over distances of fifty miles or moreand gives them warning of what he has observed. Of course, they likewise have
been on the watch, and by such means the entire forest is and by a com plete fire alarm system.

The telephone wires run in all directions through the forest-the instrudistributed that a ranger can always put himself, at brief notice, in communication with other guards, to give informa-
tion or to call for help. It is a matter of no little difficulty to keep the service always in first-rate running order, for
falling trees, blown down by storms, are liable at any time to dislodge or break the wires. When a fire has been located
the first thing requisite is to get as many men as possible to the spot to fight it. plies, which have to be brought long distances over difficult trails. Formerly
this was a very arduous matter, involving long delays, for a week might easily visions, etc., from the nearest source of supply to the scene of active operations and meanwhile the fire burned on. The obstacle has been overcome to a great ous parts of the forest, depots which ar drawn upon in any emergency. Another means of fire warning of much situated on some eminence, such as lare mountain top or rock formation that and notice of a fire is given in the day time by waving flags, or flashing th sun's rays from mirrors. The method is
very similar to that of the army signal of wooden framework with a railed plat orm, possibly an inclosure at the top an be obtained. Each forest watcher is usually provided with a marine glass as well as a signal mirror, so that in the western
mountains, with the aid of the lens, he has a range of 25 to 50 miles. The watch tower is always located so as to be seen
distinctly from one of the forest stations distinctly from one of the forest stations,
and a ranger is continually on duty. during the day to look for signals. At some
of the watch towers gasoline torches are

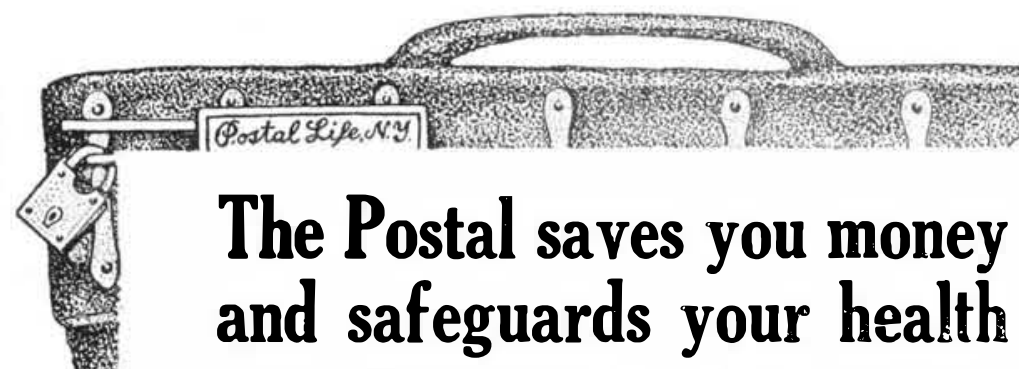

7 HOUGHTFUL people throughout the

LIFE INSURANCE COM PANY

because, first, it supplies sound legal-reserve protection at lower net cost than any other company and, second, because it performs at important servic

The Company cuts out all middlemen

agents; it deals direct -with the public; its polic

holders save, and may deduct from their first

premium (monthly, quarterly, semi-annual or

annual), a guaranteed commission-dividend (rang-

to what other companies pay out the first year ${ }^{35}$ das

to their agents.

In subsequent years, POSTAL LIFE policyholders can deduct the agent's renewal-commission of $71 / 2 \%$ of the premium as paid; also an offece-expense saving 0

\section{Dividend of $2 \frac{1}{2} \% / \begin{aligned} & \text { Guaranteed } \\ & \text { in the Policy }\end{aligned}$}

The Company also apportions and
pays the usual contingent dividends that
in time to to check or cure it.

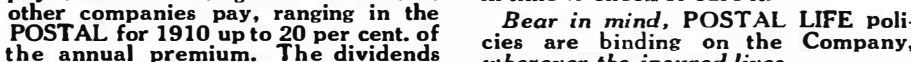
apportioned and paid this year will be

\section{Furthermore, the Company's Health
Bureau performs an important service \\ in health preservation by issuin
Health-Bulletins for the benefit of $i$ to

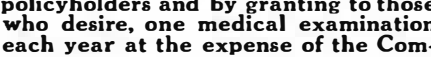
By doing business through the maiis
- direct the Company is able to effect important hevings for polichyldolders and
also to bring the benefits of insurance. the remotest sections of the cuontr.",
thus performing $\alpha$ g enuine public ser-

For the reasons here stated and others, the POSTAL LIFE is justly designated "The Company of Conservation" - of money and of health.

Twill pay you to find out just what you can save on an standard form of policy, provided you are an acceptable risk.

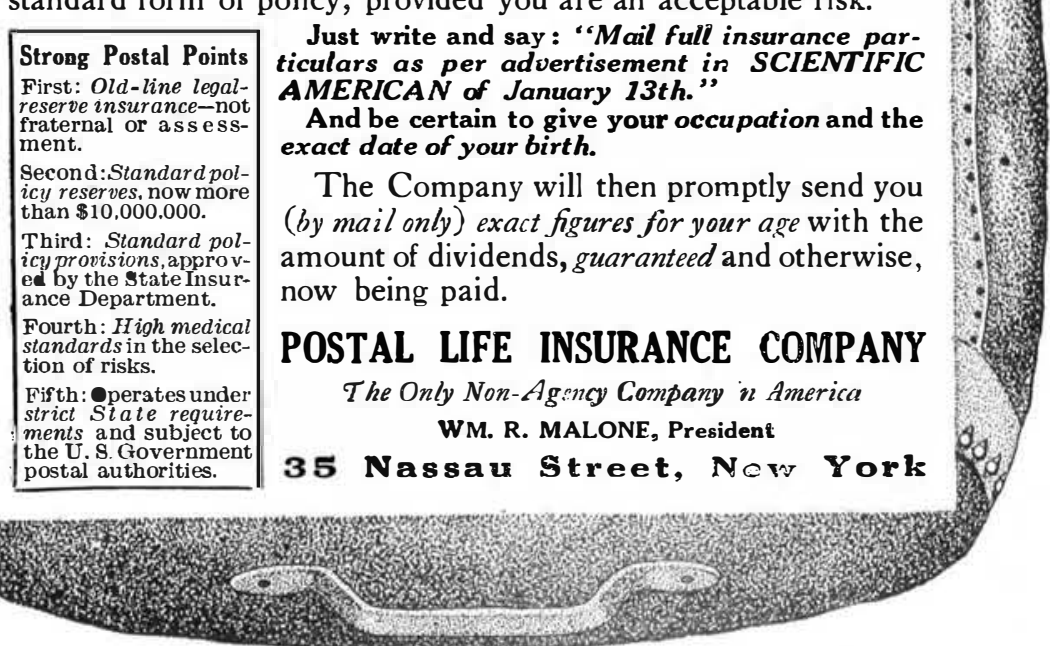

THE EDISON CONCRETE HOUSE
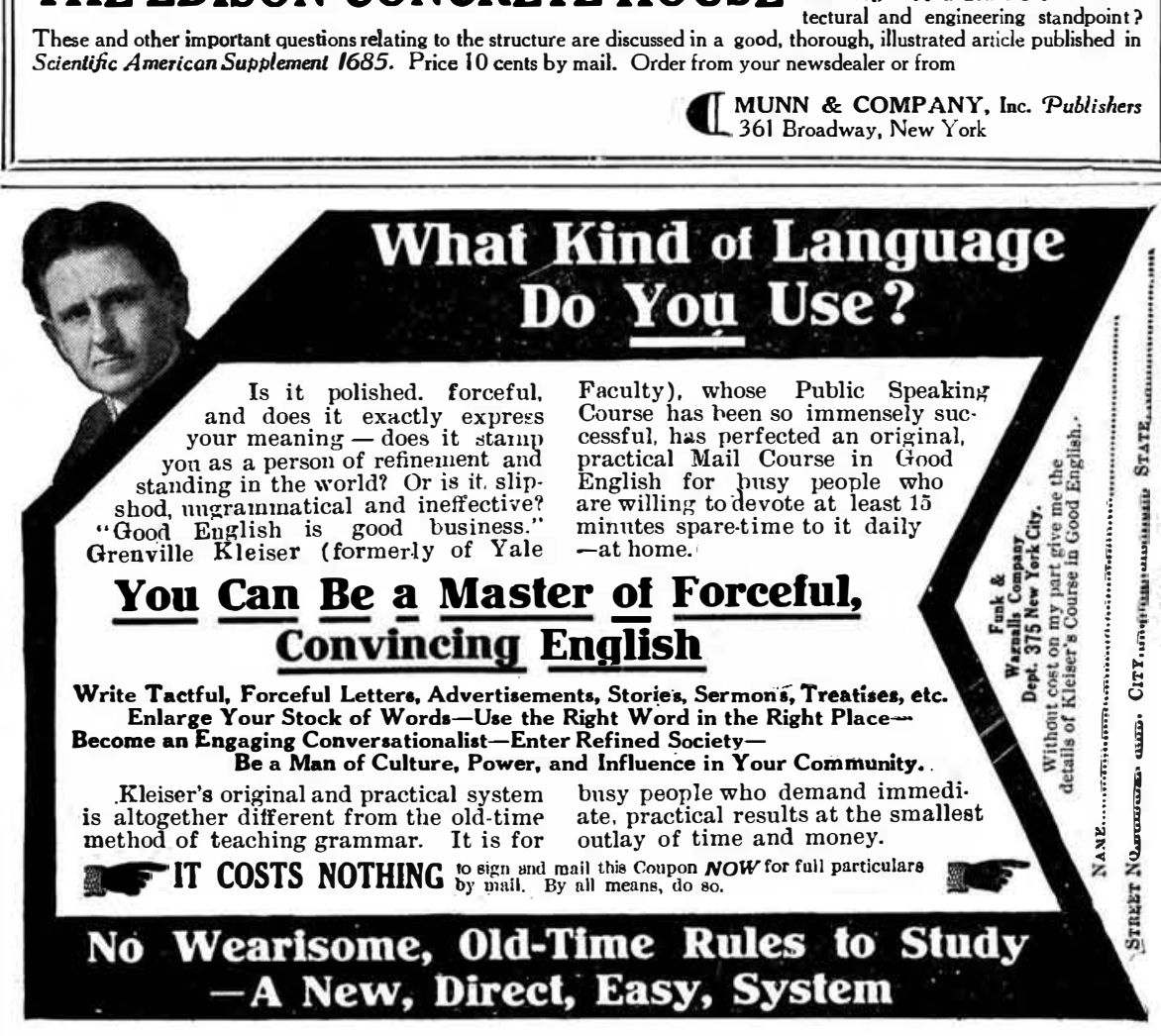


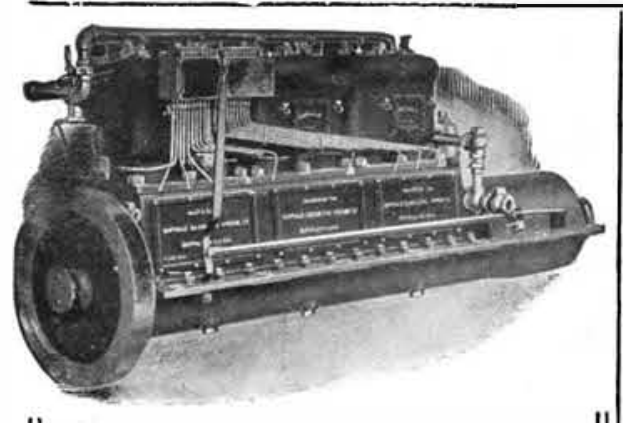

BUFFALO MARINE ENGINES

combine endurance, speed and simplicity of operation. They are built in 20 sizes -3 to 125 h.p. - for launches, speed operate on gasolene, kerosene or distillate. The Engive of Constant Service ASK FOR OUR NEW CATALOGUE

BUFFALO GASOLENE MOTOR CO. 1300-10 Niagara St., Buffalo, N. Y.
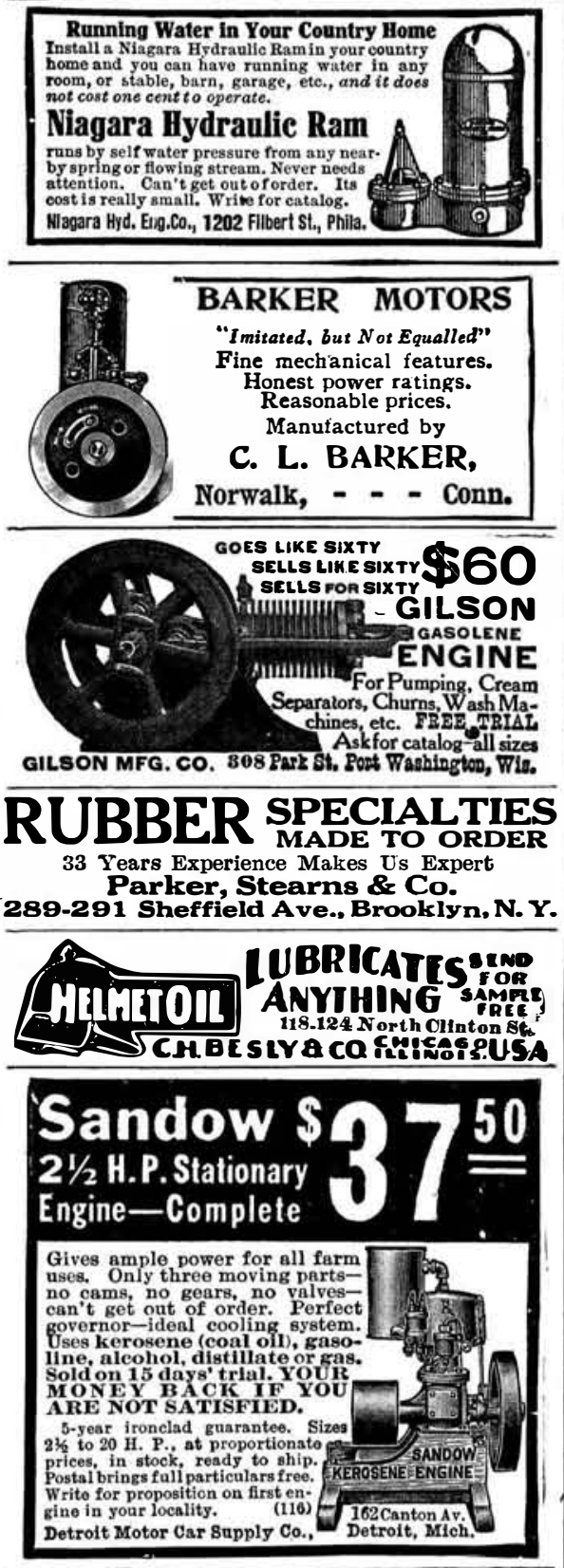

Use KEROSENE Engine FREE!

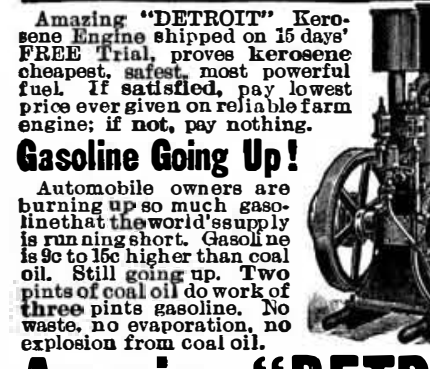

\section{Amazing "DETROIT"}

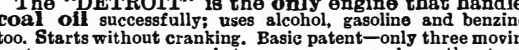

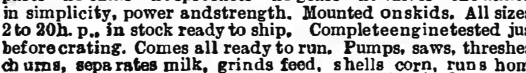

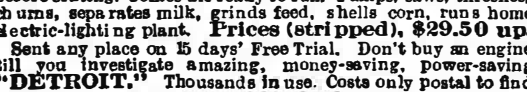

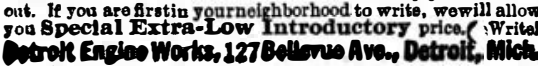

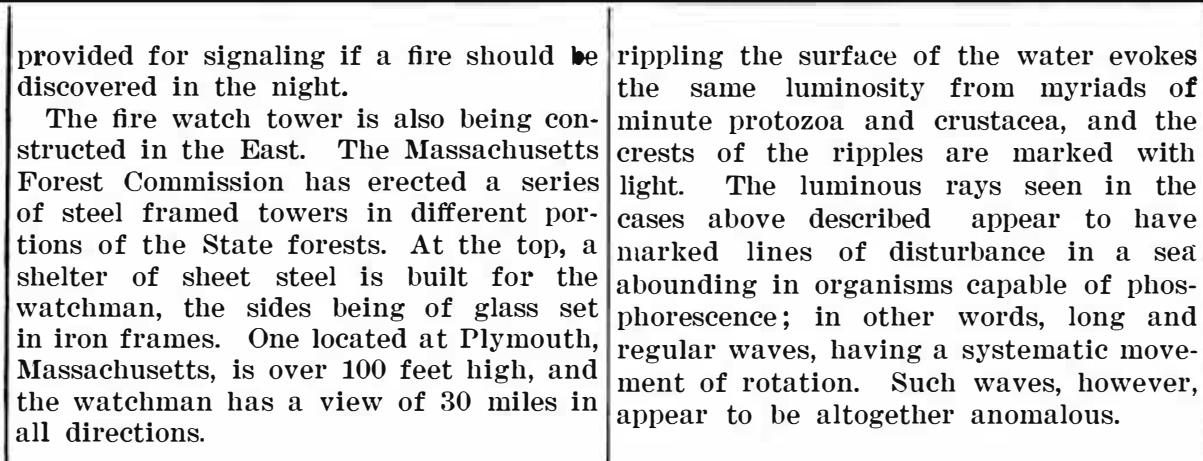

Curious Light Phenomena of the The Highest Balloon Ascent and Indian Seas

Other Achievements of the Weather Bureau

The captain was especially struck by $T$ UCKED away in a corner of the anthe fact that the larger spots of phos- nual report of the Chief of the phorescence in the sea appeared to light
up more brightly as the rays reached
year is the casual statement that a
woureal them, and to fade out in the dark in-
tervals. When the center was right
South Dakota, September 1st, 1910, by
sound abeam the rotation was so fast that the the aerological staff of the Mt. Weather rays passed about once a second. When spots of phosphorescence for some time
lighted up at regular intervals, as if miles above sea-level. This fact is in no way exploited, and the reader is left to (1)

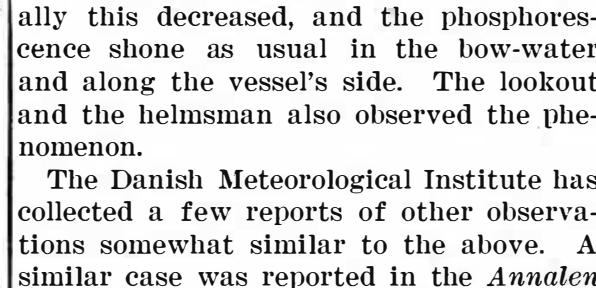
tions somewhat similar to the above. A
similar case was reported in the Annalen
der Hydrographie und maritim Mete orologie, 1899, p. 483, as follows: On
November 21st, 1897, the German ship
"Arethusa" encountered a curious illumin "Arethusa" encountered a curious illumin-
ation of the sea after midnight, when in
the Bay of Bengal, lat. 14.2 degrees N.,
long. 96.5 degrees E. As far as the eye
could reach the surface of the water
shone with myriads of lights, which the
officers declared had the effect of search-
lights in a hazy atmosphere. The ship's
log says: "It was a splendid but also an
uncomfortable sight." At 2 A. M. it be-
gan to rain, and the phenomenon sud-
denly disappeared. The wind was southsoutheast and east-southeast, its force 西 "Valentijn." At midnight August 12th, 1910 , this vessel was near the Natuna course was magnetic south, the speed
eight knots. Suddenly the easterly
horizon became illuminated with a light
which commenced to oscillate rapidly and
romen passed regularly. The phenomenon soon passed
into a rotation of flashes above the water. It looked like a horizontal wheel, turn-
ing rapidly, the spokes being the rays of ing rapidly, the spokes being the rays of
light running over the water. The rolight running over the water. The ro-
tation was against the sun and very regu-
lar, one ray passing every half second lar, one ray passing every half second.
The bundles of rays diverged very little The bundles of rays diverged very little
and were not curved. The center could not be discerned as an isolated point.
Gradually the rays grew clearer and
somewhat narrower, until the source of
light appeared to be beneath the ship. light appeared to be beneath the ship.
The water around the ship seemed to be
in rapid oscillating motion, and it was in rapid oscillating motion, and it was
as bright as at full moon (the moon had
set at $10 \mathrm{P}$. M.). This lasted about five set at $10 \mathrm{P}$. M.). This lasted about five
minutes; then the rotation recommenced
with the center on the opposite side of the ship. The rotating rass gradually decreased in brilliancy and breadth, and
at 12:40 A. M. the phenomenon had quite
disappeared in the northwest to west. disappeared in the northwest to west.
In this case the ordinary phosphoresIn this case the ordinary phosphores-
cence of the water was not observed. The cence of the water was not observed. The
sea was rather smooth and the air clear.
The phenomenon was observed by the captain, first and second mates, and first somewhat uncomfortable impression.
Similar observations have occasionally
been reported to the Meteorological Of fice at London by the captains and fice at London by the
ficers of British ships.

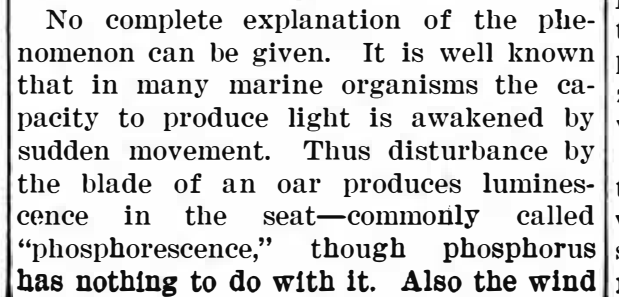
nomenon can be given. It is well known
that in many marine organisms the capacity to produce light is awakened by
sudden movement. Thus disturbance by
the "phosphorescence," though phosphorus sea-have at last begun to yield usefu
Practical Books Popular Hand Book for Cement \& Concrete Users

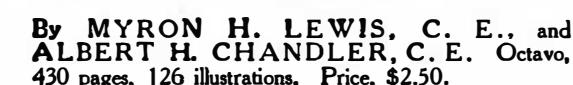
A A concise and comprehensive treatise on the principles and
methods employed in the manufacture and use of concrete and
its oroducts in all classes of moder w work. It is a standard
work of reference covering the various uses of concrete both
plain and reinforced. Everything of value tothe concrete user is

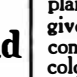

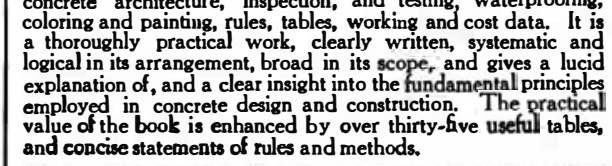

\section{Standard Practical}

Plumbing

By R. M. STARBUCK, Octavo, 406 pages,

T This is a complete practical treatise and covers the subject of
modern plumbing in all its branches. It treats exhaustively on
the skilled work of the plumber and the theory underlying

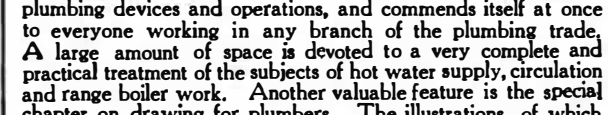

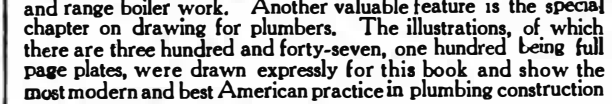
Drop Forging, Die Sinking and Machine Forming of Steel

341 pages, 304 illustrations. Price, $\$ 2.50$.

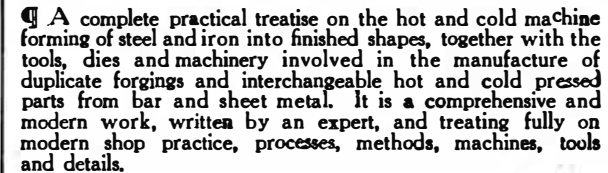

Dies: Their Construction and Use for the Modern Working of Sheet Metals

By JOSEPH V. WOODWORTH. Octar

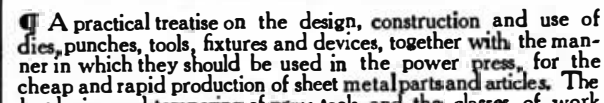

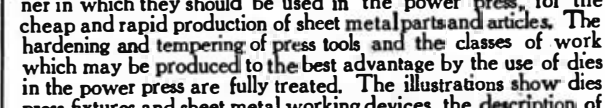

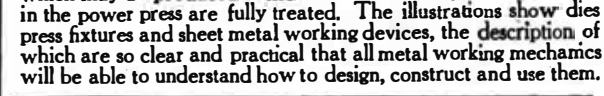

Punches, Dies and Tools for Manufacturing in Presses

By JOSEPH V. WOODWORTH. Octavo, T. This work is a companion to the author's sementary work
entitled "Dies Their Construction and Use." It doess ont go into

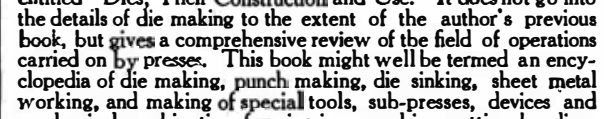
working, and making of special tools, sub-presses, devices and
mechanical combinations for piercing, punching, cutting, bending,
forming, drawing, compressing and assembling sheet metal parts
and also articles of other materials in machine tools.

American Tool Making and Interchangeable

Manufacturing

By JOSEPH V. WOODWORTH. Octavo.
535 page 601 illustrations. Price, $\$ 4.00$.

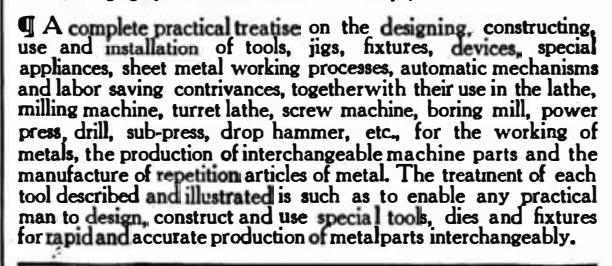

Any of these books will be sent, postpaid, on receipt of advertised price 